\title{
NANO-CALIBRATION STANDARD WITH MULTIPLE PITCH AND STEP HEIGHT VALUES
}

\author{
Gorana Baršić, Biserka Runje, Vedran Šimunović
}

Original scientific paper In 2011 Croatian National Laboratory for Length (HMI/FSB-LPMD) developed calibration standards which have been physically implemented in cooperation with the company MikroMasch Trading OU and the Ruđer Bošković Institute. Specific design of standards makes them suitable for calibration of optical instruments, stylus instruments, scanning electron microscopes, atomic force microscopes and scanning tunnelling microscopes. Therefore, the developed calibration standards greatly contribute to the reproducibility of measurement results for groove depth well as the $2 \mathrm{D}$ and $3 \mathrm{D}$ roughness parameters obtained by various measuring methods. After a number of measurements conducted on developed standards, based on which new knowledge was acquired, HMI/FSB-LPMD designed a new standard for the field of dimensional nanometrology. This paper presents the design of a new standard that is still suitable for calibration of different types of measuring instruments, i.e. methods, but has a larger measurement capability in terms of measuring ranges in vertical and lateral direction.

Keywords: nanometrology; calibration standards; reproducibility

Etalon za nanomjeriteljstvo s višestrukim vrijednostima koraka i brazda

Izvorni znanstveni članak 2011. godine uHrvatskom nacionalnom laboratorijuza duljinu (HMI/FSB-LPMD) razvijeni su etaloni za umjeravanje, a koji su izrađeni u suradnji s tvrtkom MikroMaschTrading OU i Institutom Ruđer Bošković. Specifični dizajn etalona čini ih prikladnim za umjeravanje optičkih mjernih uređaja, uređaja s ticalom, skenirajućih elektronskih mikroskopa, mikroskopa atomskih sila i skenirajućih tunelirajućih mikroskopa. Stoga razvijeni etaloni uvelike pridonose obnovljivosti rezultata mjerenja dubine brazde i 2D i 3D parametara hrapavosti dobivenih različitim mjernim metodama. Nakon niza provedenih mjerenja na novim etalonima, temeljem kojih su stečena nova znanja, u HMI/FSB-LPMD-u osmišljeni su novi etaloni za područje dimenzionalnog nanomjeriteljstva. U ovom radu predstavljen je dizajn novog etalona, koji je još uvijek prikladan za umjeravanje različitih tipova mjernih uređaja, ali ima veće mogućnost mjerenja u smislu mjernih raspona u vertikalnom i lateralnom smjeru.

Ključne riječi: nanomjeriteljstvo; etaloni; obnovljivost

\section{Introduction}

In 1986 first roughness reference standards made of silicon were produced at the Laboratory for precise measurements of length (LFSB), which is now a part of Croatian Metrology Institute (HMI) designated as HMI/FSB-LPMD. [1] Until then, roughness standards were made either from steel or glass. Due to world-class quality of these standards and their outstanding metrological characteristics, they were used in several European countries; among others, standards are currently being used as roughness reference standards in Italy, Slovenia, Croatia and Serbia.

After 27 years of use, a research of metrological characteristics on two silicon roughness standards was conducted. Time stability of metrological characteristics was focused on calibration results of two primary standards for roughness in Croatia provided by several national metrology institutes. The results of analysis indicate the outstanding quality of the first roughness reference standards made from silicon [2].

However, especially during the last decade, there has been significant progress in the field of nanotechnology, which led to the development of new measuring equipment. The above mentioned standards cannot fully meet metrological requirements in the field of nanometrology due to their size, production technology and measuring features. Because of very positive experience with the existing HMI/FSB-LPMD roughness reference standards, it was decided to use them as the basis for the development of a new calibration standard.

The research began with identifying possible limitations in the procedure for groove depth measurements on the HMI/FSB-LPMD roughness standards. In order to include as many measuring instruments, i.e. measurement methods in this research, HMI/FSB-LPMD launched EURAMET Project 1012, Limitations of Methods for Measuring Groove Depth. Project was launched in 2008 and carried out in collaboration with the national metrology institutes of Italy (INRIM), Egypt (NIS) and Croatia (LFSB); and the Ruder Boskovic Institute (RBI) of Zagreb, Croatia, as an associate participant. Results were evaluated in accordance with international rules for evaluating intercomparison results by using advanced calculation algorithms [3].

Based on the requirements for calibration standards from the overview published by PTB $[4,5]$, as well as from measurement results obtained within EURAMET Project 1012 [6], a model of new calibration standard has been proposed.

\section{Design of developed calibration standard}

In $2011 \mathrm{HMI} / \mathrm{FSB}-\mathrm{LPMD}$ developed calibration standard that has two measurement areas to ensure the ability to measure groove depths, as well as $2 \mathrm{D}$ and $3 \mathrm{D}$ roughness parameters in the field below $50 \mathrm{~nm}$. One surface is a sequence of rectangular $\mathrm{SiO}_{2}$ grooves, while the second measurement area consists of three wide rectangular $\mathrm{SiO}_{2}$ grooves.

Both measuring surfaces have the same nominal value of the groove depth, thus ensures a link between them. Two types of samples were manufactured; one with nominal value of the groove depths of $20 \mathrm{~nm}$ and the other with $50 \mathrm{~nm}$.

The impact of the measured calibration standard in uncertainty budget calculation is the one with the most 
influence. Therefore, the reductions of the measurement area have been considered in order to help to ensure better uniformity of the standard measuring surfaces.

Since LFSB has more than 20 years of positive experience with $\mathrm{Si} / \mathrm{SiO} 2$ as materials for standard structures and since silicon is the most widely used material today for calibration standards in the field of dimensional nanometrology $[4,5]$, standards were made out of silicon as well. Fig. 1 presents developed calibration standard.

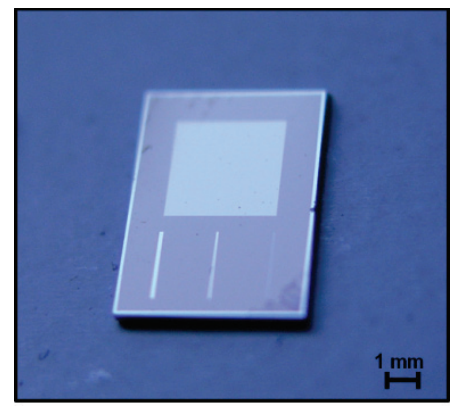

Figure 1Developed calibration standard

Due to the transparency and electrical nonconductivity of the $\mathrm{SiO}_{2}$ layer, $\mathrm{Si} / \mathrm{SiO}_{2}$ structures must be coated with a thin metallic layer, that provides conditions for optical interference measurements and measurements that require conductivity of the measurement surface.

Therefore, the selected layer must provide the following:

- excellent mechanical properties;

- good adhesion;

- maintenance of the geometry of the primary $\mathrm{Si} / \mathrm{SiO}_{2}$ structure (same level of deviation from parallelism and flatness);

- required optical properties;

- electrical conductivity.

A good candidate meeting all these requirements is chromium. Standards were coated at the Ruđer Bošković Institute by evaporation using electron beam-physical vapour deposition. The thickness of the chromium layer was about $50 \mathrm{~nm}$. In Fig. 2 a cross-section of developed calibration standard is presented.

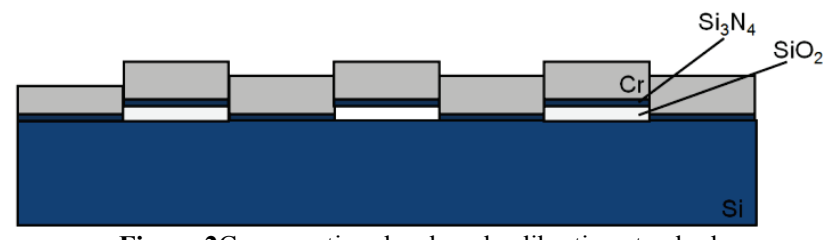

Figure 2Cross-section developed calibration standard

Metrological characteristics of described calibration standard greatly contribute to the traceability chain [7], as well as ensure traceability in the industry, in particular the reliability of the results in the field of roughness metrology [8].

\section{Metrological features of developed calibration standards}

In order to determine the characteristics of developed calibration standards, measurements were performed using contact profilometer, interference microscope, AFM and STM. All instruments were calibrated using certificated artefacts. Two standards were measured, one with a nominal groove depth value of $20 \mathrm{~nm}$ (marked REH 20), and the other of $50 \mathrm{~nm}$ (marked REH 50).

With regard to the method used, measurements of 2D roughness parameters $(R a, R q$ and $R z$ according to ISO 4287), 3D roughness parameters ( $S a, S q$ and $S z$ according to ISO 25178-2) and measurements of groove depths (according to ISO 5436-1) were conducted. [9].

Although there are a number of different 2D and 3D roughness parameters, the parameters chosen for the purposes of this research describe the arithmetic mean and mean square deviation of the profile $(R a, R q)$ and on the surface $(S a, S q)$. On the other hand, the selected 2D and 3D parameters $(R z$ and $S z)$ indicate the maximum deviations of the roughness profile and measured surface on the z-axis. The selected roughness parameters are those that are usually provided in certificates issued for roughness calibration standards. Fig. 3 and 4 present summarised groove depth measurement results on REH 20 and REH 50 standards where intervals represent 2 experimental standard deviations (95\% probability).

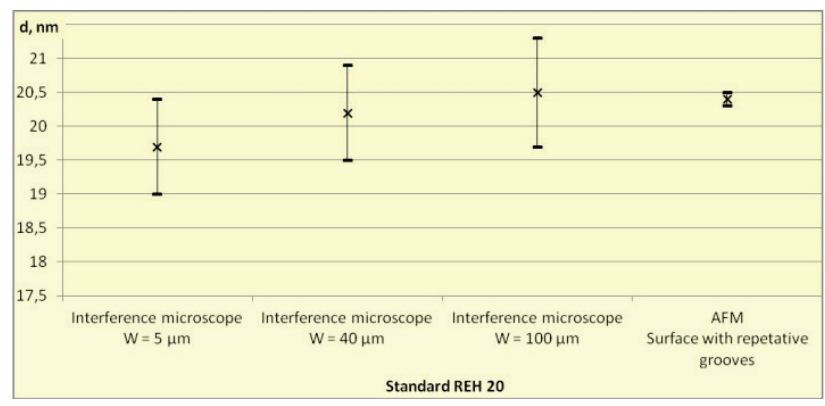

Figure 3 Groove depth measurement results on REH 20 standard

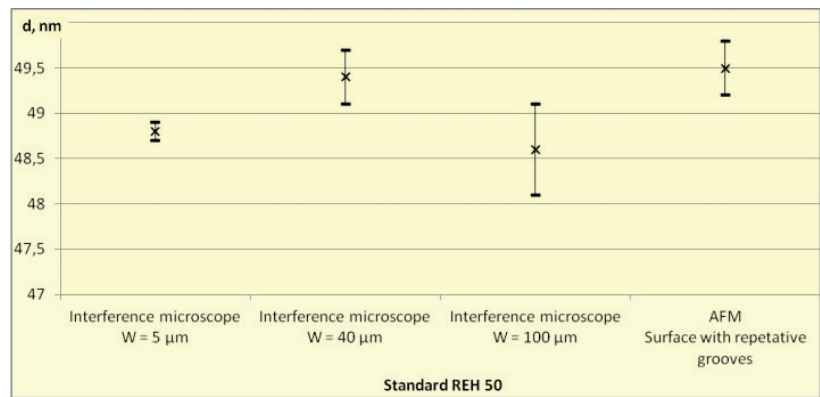

Figure 4 Groove depth measurement results on REH 50 standard

Despite the fact that the grooves were measured on different areas on the calibration standards, achieved results revealed a good uniformity within standard's measuring areas, as well as a good comparability between measuring areas. 3D roughness parameters were measured using AFM and STM. Measurement results are presented in summary Tab. 1.

Good agreement of the roughness parameters $S a$ and $S q$ between the measured surfaces has been found. Estimated standard deviation of the parameter $S a$ and $S q$ corroborates the uniformity of the measured structures.

However, the measurement results of the parameter $S z$ highlight the significant influence of the extremes, such as impurities, on the measurement results obtained for that parameter. 


\begin{tabular}{|c|c|c|c|c|c|}
\hline \multirow{2}{*}{ Standard } & \multirow{2}{*}{ Instrument } & \multirow{2}{*}{ Scanning area } & \multicolumn{3}{|c|}{ 3D roughness parameter } \\
\hline & & & $S a, \mathrm{~nm}$ & $S q, \mathrm{~nm}$ & $\mathrm{Sz}, \mathrm{nm}$ \\
\hline \multirow{5}{*}{ REH 20} & \multirow{3}{*}{ AFM } & Area 1 & 10,0 & 10,2 & 73,2 \\
\hline & & Area 2 & 9,8 & 10,1 & 120,0 \\
\hline & & Area 3 & 9,8 & 10,1 & 201,5 \\
\hline & \multirow{2}{*}{ STM } & P-I & 9,1 & 10,4 & 43,1 \\
\hline & & P-II & 0,7 & 1,1 & 11,9 \\
\hline \multirow{3}{*}{ REH 50} & \multirow{3}{*}{ AFM } & Area 1 & 23,3 & 24,0 & 265,6 \\
\hline & & Area 2 & 24,5 & 24,9 & 172,4 \\
\hline & & Area 3 & 24,9 & 25,1 & 188,4 \\
\hline
\end{tabular}

2D roughness parameters were measured only on contact profilometer. The results are presented in Tab. 2 where $\bar{x}$ stands for arithmetic mean of measured roughness parameter and $s$ are estimated standard deviation. The parameters were measured on three roughness profiles.

Table 2 Results of 2D roughness parameters

\begin{tabular}{|c|c|c|c|c|c|c|}
\hline & \multicolumn{2}{|c|}{$R a, \mathrm{~nm}$} & \multicolumn{2}{c|}{$R q, \mathrm{~nm}$} & \multicolumn{2}{c|}{$R z, \mathrm{~nm}$} \\
\hline & REH 20 & REH 50 & REH 20 & REH 50 & REH 20 & REH 50 \\
\hline$\overline{\boldsymbol{x}}$ & 9,7 & 23,1 & 10,2 & 24,9 & 44,6 & 185,6 \\
\hline$s$ & 0,1 & 0,1 & 0,2 & 0,2 & 21,9 & 2,3 \\
\hline
\end{tabular}

The 2D roughness parameters from Tab. 2 confirm the conclusions related to the results of the $3 \mathrm{D}$ parameters given in Tab. 1. Namely, the estimated standard deviation of the parameter $R a$ and $R q$ verifies the uniformity of the measured structures. However, the measurement results of the parameter $R z$ once again highlight the significant influence of the extremes on the measurement results obtained for that parameter.

\section{Proposed new design for calibration standard}

The research of metrological characteristics on two silicon roughness standards after 27 years of use reveals that the uniformity of surfaces was not changed i.e. measurement surfaces suffered no significant damage that would impair metrological characteristics of these standards. Based on the results from that study it was decided that new calibration standards will also be made of silicon.

Measurement results obtained on physically realized standards confirmed the uniformity of the standard measurement surfaces in both, lateral and vertical, directions. However, these standards are limited with regard to only one value of parameter $R S m$, and one nominal value of groove depth $d$. Furthermore, the realized calibration standards are $450 \mu \mathrm{m}$ thick. In order to facilitate handling, the standards were glued to plan parallel glass.

For reasons above discussed authors' proposed a new design of calibration standard for the field of dimensional nanometrology, Fig. 5. The dimensions of standard are $5,5 \mathrm{~mm} \times 5,5 \mathrm{~mm}$, with thickness of $2 \mathrm{~mm}$ which allows easy handling with sample.

Measurement structures are rectangular silicon oxide steps. The surface of standards is made conductive and opaque by coating with a thin chromium layer. Standard has four measurement areas to ensure the ability to measure groove depths, as well as 2D and 3D roughness parameters in the field below $100 \mathrm{~nm}$.

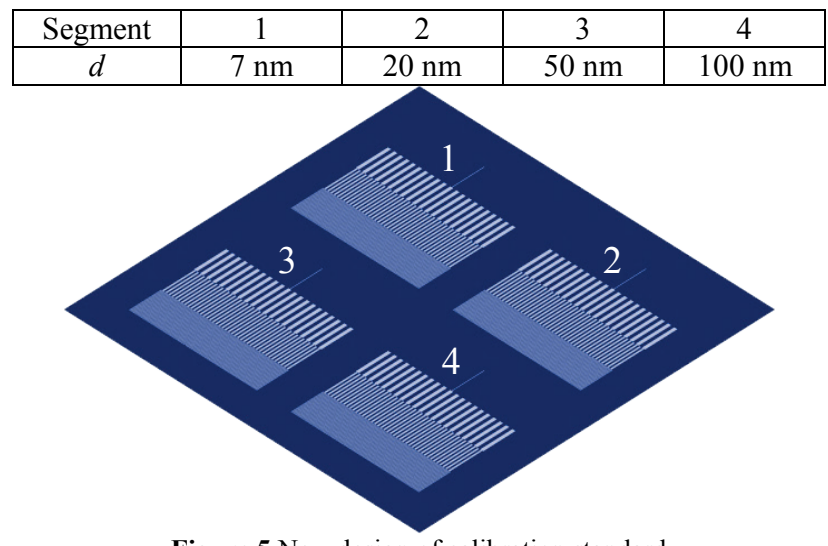

Figure 5 New design of calibration standard

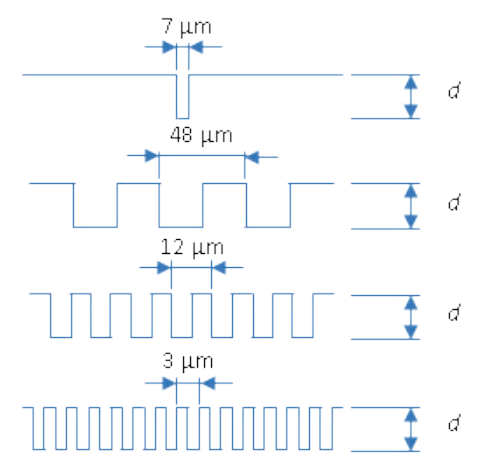

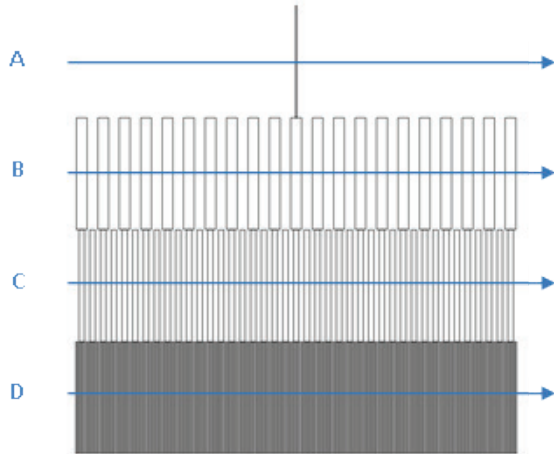

Figure 6 Measurement areas

The areas differ with respect to the nominal values of vertical components of $7 \mathrm{~nm} ; 20 \mathrm{~nm} ; 50 \mathrm{~nm}$ and $100 \mathrm{~nm}$. On each area there are three sections with a sequence of rectangular silicon oxide steps with different nominal values of parameter $R S m$ of $3 \mu \mathrm{m}, 12 \mu \mathrm{m}$ and $48 \mu \mathrm{m}$ and one section with one wide rectangular step, Fig. 6. 
Sections with a sequence of rectangular silicon oxide steps serve for calibration of lateral axis of measuring instruments. Grooves with different lateral sizes are chosen in such a way that the calibration standard can be measured by different types of instruments. The probe dimensions have been considered in the design of the measurement areas.

Sections with only one wide rectangular groove serve for calibration of vertical axis of measuring instruments.

In this way on one artifact there are four standards for groove depths and three lateral standards that extend measurement capability in terms of the measuring ranges in vertical and lateral direction.

The proposed design with selected measuring ranges and used materials makes this standard suitable for calibration of different types of measuring instruments, i.e. methods.[10]

\section{Conclusion}

HMI/FSB-LPMD has a long tradition in design of roughness calibration standards. In fact, first roughness reference standards made of silicon were produced at HMI/FSB-LPMD in 1986. A research of metrological characteristics on two roughness standards, after 27 years of continuous use, indicates outstanding quality of the first roughness reference standards made of silicon.

In $2011 \mathrm{HMI} / \mathrm{FSB}-\mathrm{LPMD}$ developed roughness standards for the field of dimensional nanometrology in cooperation with the company MikroMasch Trading OU and Ruđer Bošković Institute. A comprehensive research confirmed the suitability of standards to be used for calibration of optical instruments, as well as for stylus instruments, scanning electron microscopes, atomic force microscopes and scanning tunneling microscopes.

New design of calibration standards proposed in this paper brings the best from realized standards but extend measurement capability in terms of the measuring ranges in vertical and lateral direction. With proposed design on one artifact there will be four standards for calibration of vertical axis and three lateral standards. Moreover, those three lateral standards are multiplied with respect to the four sections with different nominal values of vertical components.

After production of a new calibration standard a research will be carried out in order to evaluate the expected metrological characteristics. This research will include measurements of groove depth and pitch using different measuring devices (methods) in order to determine the level of the repeatability and reproducibility of the measurement results and a study on the suitability of a surface with repetitive grooves for the reproduction of $2 \mathrm{D}$ and $3 \mathrm{D}$ roughness parameters in the field of nanometrology.

\section{References}

[1] Dusman, F.; Mahović, S. A proposal of a method for gauging of calibration specimens for use with stylus in instruments applied in the measurement of surface texture. // IMEKO XI Instrumentation for the 21st century, Huston, Texas, USA, October 1988
[2] Baršić, G.; Mahović, S.; Katić, M.; Šimunović, V. Long term stability of silicon roughness standards. // Euspen, $14^{\text {th }}$ International Conference of Precision Engineering and Nanotechnology, Dubrovnik, Croatia, 2014.

[3] Acko, B.; Sluban, B.; Tasic, T.; Brezovnik, S. Performance metrics for testing statistical calculations in interlaboratory comparisons. // Advances in Production Engineering \& Management. 9, 1(2014), pp. 44-52. DOl: 10.14743/apem2014.1.175

[4] Review of standards by measurement techniques http://www.ptb.de/nanoscale/standards/Standards_Measure ment_Techniques_preliminary.pdf

[5] Review of standards by their design http://www.ptb.de/nanoscale/standards/Standards_prelimin ary.pdf

[6] Baršić, G.; Mahović, S.; Picotto, G. B.; Amer, A. M.; Runje, B. Groove depth measurements at the Croatian National Laboratory for Length (LFSB), Meas. Sci. Technol. 22 (2011).

[7] Lipus, C. L.; Matus, M.; Acko, B. Optimization of Calibrating HeNe Laser Interferometers by Sample - Period Simulation. // International Journal of Simulation Modelling. 12, 3(2013), pp. 154-163.

[8] Simunovic, G.; Simunovic, K.; Saric, T. Modelling and Simulation of Surface Roughness in Face Milling. // International Journal of Simulation Modelling. 12, 3(2013), pp. 141-153.

[9] Baršić, G.; Mahović, S.; Zorc, H. Development of nanoroughness calibration standards. // Meas. Sci. Technol. 23 (2012).

[10] Mudronja, V.; Baršić, G.; Runje, B. Calibration of the Vertical Measuring System of Stylus Instrument Perthometer S8P. // Tehnički vjesnik-Technical Gazette. 21, 1(2014), pp. 141-145.

\section{Authors' addresses}

Dr. sc. Gorana Baršić, dipl. ing.

Faculty of Mechanical Engineering and Naval Architecture Ivana Lučića 1, 10000 Zagreb, Croatia E-mail: gorana.barsic@fsb.hr

Prof. dr. sc. Biserka Runje, dipl. ing.

Faculty of Mechanical Engineering and Naval Architecture Ivana Lučića 1, 10000 Zagreb, Croatia E-mail: biserka.runje@fsb.hr

Dr. sc. Vedran Šimunović, dipl. ing.

Faculty of Mechanical Engineering and Naval Architecture Ivana Lučića 1, 10000 Zagreb, Croatia E-mail: vedran.simunovic@fsb.hr 